\title{
低炭素鋼の塑性変形されたオーステナイトの粒界から 生成するフェライト粒の形，大きさと結晶方位
}

\author{
鳥塚 史郎* ·梅澤 修* ・津㟝 兼彰* ・長井 寿*
}

Shape, Size and Crystallographic Orientation of the Ferrite Grains Formed at Grain Boundaries of Deformed Austenite in a Low Carbon Steel

Shiro ToRizuKa, Osamu UmeZAwA, Kaneaki TsuZAKI and Kotobu NAGAI

Synopsis : The influence of plastic strain on the shape, size and crystallographic orientation of ferrite $(\alpha)$ grains formed at the grain boundaries of the deformed austenite $(\gamma)$ was studied in a $0.17 \mathrm{C}-0.3 \mathrm{Si}-1.5 \mathrm{Mn}$ steel. Specimens with a coarse $\gamma$ grain size of $300 \mu \mathrm{m}$ were compressed at $1023 \mathrm{~K}$ and cooled at $10 \mathrm{~K} / \mathrm{s}$. When the plastic strain increased to 0.4 , the shape of $\alpha$ grains changed from plate like to equiaxed, and the average length of $\alpha$ grains decreased from 12 to $6 \mu \mathrm{m}$. However, the average length did not change in the larger plastic strains up to 1.1. On the other hand, the average thickness of $\alpha$ grains was constant regardless of the plastic strain. The crystallographic orientations of the $\alpha$ grains formed at one $\gamma$ grain boundary were almost the same when the plastic strain was smaller than 0.2 and the $\alpha$ grain shape was plate like. However, the orientations were widely distributed, and most of the $\alpha / \alpha$ boundaries were high angle ones, when the plastic strain was larger than 0.4 and the $\alpha$ grain shape was equiaxed. The shape change and $\alpha$ grain refinement by the deformation resulted from the wide distribution of crystallographic orientations of $\alpha$ grains rather than from the increase in the nucleation rate. The wide distribution of crystallographic orientation of $\alpha$ grains is closely associated with the serrated austenite grain boundaries induced by the deformation.

Key words: grain size; phase transformation; plastic deformation; crystallographic orientation; low carbon steel; grain boundary; ferrite; austenite; controlled rolling.

\section{1. 緒言}

微細なフェライト $(\alpha)$ 粒組織を工業的に得る手段のひと つとして制御圧延 ${ }^{1)}$ ，すなわち塑性変形を受けた未再結晶 状態のオーステナイト $(\gamma)$ からの変態がある。従来, この 微細化は $(1) \gamma$ 粒の伸長と変形带の導入による単位体積あ たりの「粒界」面積の増加および( 2 )単位「粒界」面積あ たりの $\alpha$ 粒生成頻度の増加と関連づけられて説明されてい

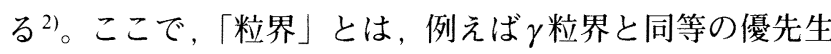
成サイトとなる変形帯なども含んでいる。(1)は $\alpha$ 粒の優 先生成サイトである「粒界」の存在密度を評価し, (2)で は「粒界」における $\alpha$ 粒の生成頻度能力を評価している。 なお, 以後本論文においては, 粒界は $\gamma$ 粒界に限定し, 変 形帯および焼鈍双晶等は含めない。

ここで $\alpha$ 粒の生成頻度能力を具体的に定量化する場合， 変態後の組織観察からは $\alpha$ 粒生成能力を持つサイトすべて が働いたかどうかを検証するのは困難であるという問題が ある。例えば先に生成した $\alpha$ 粒が速やかに成長して周囲の サイトを占有してしまえば，生成頻度を定量的に評価する ための情報を正確に得ることはできない。さらには， $\gamma$ 粒 界上に多くの $\alpha$ 粒が生成したとしても，それらが合体して しまうと生成頻度の定量的評価が不確かになる ${ }^{3)}$ 。すなわ
ち, 得られた組織から評価する限り，(2)における生成頻 度は結果論的取り扱いとなり正確な評価ができない。

粒界 $\alpha$ 粒の合体については, 飴山ら ${ }^{4)}$ が興味深い報告を している。すなわち， $\gamma$ 化温度を高温として十分粒成長さ せた場合の直線的 $\gamma$ 粒界から生成する $\alpha$ 粒は, 同一バリア ントを持つものが多く, 合体し $\gamma$ 粒界に沿ったフィルム状 $\alpha$ 粒となりやすい。一方, $\gamma$ 粒界面が湾曲している場合は, 粒界 $\alpha$ 粒の結晶方位は分散し， $\alpha$ 粒は合体せず塊状とな る。

従来より, 制御圧延・制御冷却において塑性変形量を増 加させると得られる変態 $\alpha$ 粒径がより微細になることが知 られており，上述のように粒界 $\alpha$ 粒の微細化が大きな役割 を果たすと考えられている。ところで, 飴山らが示したよ うな粒界 $\alpha$ 粒の方位分散が塑性変形量に左右され, 例えば 塑性変形量の増加とともに方位分散が進み「合体」しにく くなることが起こるとすると, 生成頻度能力の増加を伴わ ずとも粒界 $\alpha$ 粒は微細化して, 結果として見かけ上( 2 )の 生成頻度は増加することになる。しかし, 粒界 $\alpha$ 粒の形, 大きさ, 結晶方位に及ぼす塑性変形の影響について, 塑性 変形量を大きく変化させた系統的な検討は少なく, 特に微 細化と結晶方位分散の関係については報告が見あたらな i。 
従来の塑性変形を受けた $\gamma$ からの粒界 $\alpha$ 生成に関する詳 細な研究として Umemoto $5^{5}$ およびAmano $ら^{6}$ の報告があ げられる。Umemotoらは，0.12C-0.26Si-1.4Mn-0.04Nb-

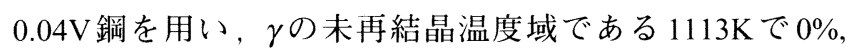
$30 \%, 50 \%$ の圧延を行い, 直ちに $953 \mathrm{~K}$ のソルバス中に投 入し，塑性変形された $\gamma$ 粒の粒界から等温変態で生成する $\alpha$ 粒の生成数を変態初期の組織観察から調べた。その結果, 圧下率 $0 \%, 30 \%, 50 \%$ に対し， $\gamma$ 粒界から生成した $\alpha$ 粒の個 数は, それぞれ, $41 / \mathrm{mm}, 214 / \mathrm{mm}, 330 / \mathrm{mm}$ であり, $\gamma$ 粒の 変形量の増加にともなって粒界からの $\alpha$ 粒の生成数が増加 することを報告している。一方，Amanoらは0.15C-0.3Si$1.3 \mathrm{Mn}$ 鋼において $1073 \mathrm{~K} て ゙$ 圧縮ひずみ 0.6 (圧下率 45\%) まで加工し，その後 973-893Kで等温変態させ, $\gamma$ 粒界か ら等温変態で生成する単位粒界長さあたりの $\alpha$ 粒生成数を 調べ，ひずみが 0.2 (圧下率 $19 \%$ ）程度で $\alpha$ 生成数は飽和 することを報告している。いずれの場合も等温変態を扱つ たものであり, 連続冷却変態の場合は不明である。また, $50 \%$ 以上の強加工後の粒界 $\alpha$ 組織については検討されてい ない。さらに， $\alpha$ 粒の結晶方位についても調べられていな け。

一方， $\alpha$ 粒の結晶方位に関しては，稲垣》および柚鳥 $ら^{8)}$ が, 制御圧延鋼の $\alpha$ 組織の変態集合組織を報告してお $り$, 両者とも, 主要方位を $\{113\}\langle 111\rangle,\{332\}\langle 113\rangle$ と同定し た。しかし，塑性変形を受けた $\gamma$ 粒界から生成した $\alpha$ 粒 個々の結晶方位については報告されておらず，塑性変形を 受けた一つの $\gamma$ 粒界から生成する $\alpha$ 粒が優先的な方位を持 つかなどの詳細は不明である。

そこで本研究では, 未再結晶 $\gamma$ 域にある変形温度での塑 性変形量を変化させ, その後, 連続冷却過程で変態生成し た粒界 $\alpha$ 粒について，特に $\alpha$ の結晶方位に注目して詳細な 検討を行った。実験に当たっては，粒界 $\alpha$ 粒のみの情報を 得るために，十分大きな $\gamma$ 粒となるようにした。検討した 塑性ひずみは 0 から 1.1 （圧下率 67\%に相当）の範囲であ り，従来の制御圧延・制御冷却で検討されてきた範囲にほ ぼ相当する。

\section{2. 実験方法}

SM490相当組成 $(0.17 \mathrm{C}, 0.3 \mathrm{Si}, 1.5 \mathrm{Mn}, 0.02 \mathrm{P}, 0.005 \mathrm{~S}, 0.001 \mathrm{~N}$; mass \%)の低炭素鋼を真空溶解, 熱間圧延により作製し, 長さ $20 \times$ 幅 $15 \times$ 厚さ $12 \mathrm{~mm}$ の大きさの試験片を切り出し た。この試験片に対して, 加工熱処理シミュレータを用い て, Fig. 1中の模式図に示す圧縮変形を以下の条件で行つ た。試験片を $1473 \mathrm{~K}$ に加熱後 $60 \mathrm{~s}$ 保持し $\gamma$ 粒径を $300 \mu \mathrm{m}$ に 調整した後， $10 \mathrm{~K} / \mathrm{s}$ で $1023 \mathrm{~K}$ まで冷却し $5 \mathrm{~s}$ 保持した後，ひ ずみ速度 $10 / \mathrm{s} に て 1$ パスで圧縮を行った。変形量は厚さ： $12 \mathrm{~mm} \rightarrow 9.6 \mathrm{~mm}$ (圧下率 $20 \%$ ), $12 \mathrm{~mm} \rightarrow 8 \mathrm{~mm}$ (压下率 $33 \%$ ) および $12 \mathrm{~mm} \rightarrow 6 \mathrm{~mm}$ (圧下率 $50 \%$ ）の 3 条件である。圧縮
後 $773 \mathrm{~K}$ まで $10 \mathrm{~K} / \mathrm{s}$ で制御冷却し，その後は放冷した。な お, Fig. 1に示す粒径測定領域の冷却速度はいずれも $10 \pm 0.5 \mathrm{~K} / \mathrm{s}$ であることを熱電対を用いて実験的に確認して いる。 $\gamma$ 粒径が $300 \mu \mathrm{m}$ の試料において変形を施さずに

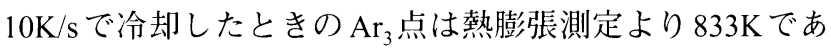
り，1023Kの圧縮開始前は $\gamma$ 単相状態であることを確認し

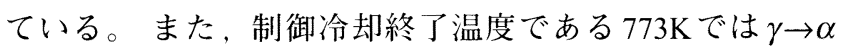
変態は完了している。

本研究で行った圧縮変形では, 試験片内部は均一には変 形されず，ひずみは試験片表面から中心部にかけて連続的 に増加する。そのため，一つの試験片で，様々なひずみの 部位を観察できる利点がある。そこで，内部の塑性ひずみ 分布を有限要素法による数值解析で求めた。なお，数值解 析結果は実験で測定したひずみ分布と一致してい た ${ }^{9)}$ 。 $\alpha$ 粒径の測定位置は, 試験片の TD軸に垂直な断面の 矢印(a), (b)で示す部分にある旧 $\gamma$ 粒界で, 粒界3 重点近傍 を除いた直線的な旧 $\gamma$ 粒界に限った。なお，測定位置では 变形の対称性のためにせん断ひずみ成分は相殺されてい る。本論文では、塑性変形量を試料における観察位置での 塑性ひずみ ${ }^{10)}$ で表す。

粒界 $\alpha$ 粒の結晶方位解析には, SEM-EBSD (Electron Back Scattering Diffraction) 法を用いた。各 $\alpha$ 粒の代表方位 を決定し，集合組織および各 $\alpha$ 粒間の方位差角について解 析を行った。方位差角の計算には，まず，各 $\alpha$ 粒の代表方 位のオイラー角を方位マトリックスに変換し ${ }^{11)}, 2 つ の ~ \alpha$ 粒の方位マトリックスからその回転行列を求めた。この回 転行列の固有ベクトルが2つの方位マトリックスの回転軸 となる。次に，回転軸に直交するひとつの任意のべクトル を決め, 回転行列によって変換する。このべクトルと元の ベクトルのなす角が方位差角となる ${ }^{12)}$ 。結晶の対称性から 24 通りの回転関係が存在するため，計算では 24 通りすべ てを計算し，その中で最も小さな回転角を方位差角とし た。

\section{3. 結果}

\section{$3 \cdot 1$ 粒界 $\alpha$ 粒の形と大きさ}

$3 \cdot 1 \cdot 1$ 粒界 $\alpha$ 粒の形の変化

Fig. 1 に試験片内部における塑性ひずみ分布の FEM計算 結果を示す。試験片厚さを $12 \mathrm{~mm}$ から $9.6 \mathrm{~mm}$ (圧下率 $20 \%$ ),

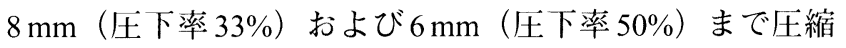
したときの塑性ひずみは, 試験片の端部から中心部にかけ て増加し，中心部の塑性ひずみは，それぞれ，0.36（圧下 率 $30 \%$ に相当），0.83（压下率 $56 \%$ に相当），2.1（圧下率 $88 \%$ に相当）であった。

Fig. 2 に $\gamma \rightarrow \alpha$ 変態後の試料の光学顕微鏡組織を示す。 Fig. 2(a), (b)は塑性ひずみ 0 と 0.05 の部位のマクロな組織写 真である。Fig. 2(a)の塑性ひずみ 00 領域では, $\alpha$ 粒が旧 $\gamma$ 


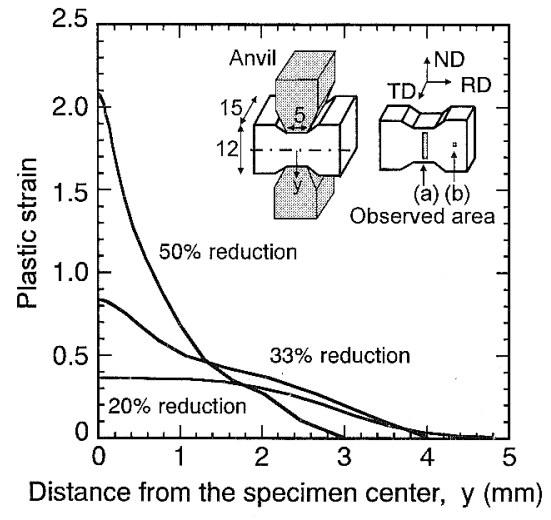

Fig. 1. Plastic strain obtained from FEM calculation at the distance from the specimen center for the specimens compressed by 20,33 and $50 \%$ in reduction at $1023 \mathrm{~K}$.

粒をとりかこんでおらず，粒界 $\alpha$ が生成しなかった $\gamma$ 粒界 も認められる。一方，塑性ひずみが 0.050 領域では(Fig. 2(b))，粒界 $\alpha$ 粒によって $\gamma$ 粒は囲ま机て打り，ほぼすべて の $\gamma$ 粒界において粒界 $\alpha$ が生成しているようである。この ことは，わずかの塑性ひずみによって粒界 $\alpha$ の生成が促進 されることを示している。

塑性ひずみが 0.05 の領域で $\gamma$ 粒界に生成する $\alpha$ 粒の形に 注目すると，アスペタト比が 2 以上の板状が支配的である (Fig. 2(c))。このような板状をした粒界 $\alpha$ は塑性ひずみが 0.2 で数多く観察さ机る(Fig. 2(d))。しかし, 塑性ひずみ が 0.4 以上に大きくなると $\alpha$ 粒の形は等軸状が大半となっ ている(Fig. 2(e)〜 (g))。このように塑性ひずみの増加に よって板状の粒界 $\alpha$ 粒の生成頻度が減少し, 粒界 $\alpha$ 粒の形 状は等軸状に変化する。

一方， $\gamma$ 粒内に生成する $\alpha$ に注目すると，塑性ひずみ 0.95 (Fig. 2(g))までは, 針状のウィドマンステッテン $\alpha$ が 支配的である。しかし，塑性ひずみが 1.1 になると， $\gamma$ 粒 内に打いても等軸 $\alpha$ 粒が支配的になっている $\gamma$ 粒が認めら れる(Fig. 2(h))。これら等軸 $\alpha$ は, 変形帯と総称される $\gamma$ 粒 内に導入された核生成サイトより生成したものである。さ らに，Fig. 2には示していないが，塑性ひずみ2では，い ずれの $\gamma$ 粒内からも等軸 $\alpha$ 粒が列状に生成するようにな り，旧 $\gamma$ 粒界が識別できなかった。このため以下では，ほ とんどの $\gamma$ 粒界に $\alpha$ 粒が生成し, かつ, 旧 $\gamma$ 粒界が識別で きる塑性ひずみ 0.05 以上 1.1 以下の範囲を取り扱うことに した。

$3 \cdot 1 \cdot 2$ 粒界 $\alpha$ 粒の大きさの変化

塑性ひずみと粒界 $\alpha$ 粒の大きさの関係索 Fig. 3に示す。 Fig. 3(a)は粒界に垂直な方向の $\alpha$ 粒切片（ $\alpha$ 粒の厚さと呼 ぶ）老し，Fig. 3(b)は粒界に平行な方向の $\alpha$ 粒切片（ $\alpha$ 粒の長さと呼ぶ）示す。黒丸の列は1-5本の $\gamma$ 粒界から 生成した $\alpha$ 粒の厚さまたは長さを表し, 黒丸一つ一つが 1 個の $\alpha$ 粒の值を表す。白丸は一つの $\gamma$ 粒界における平均值
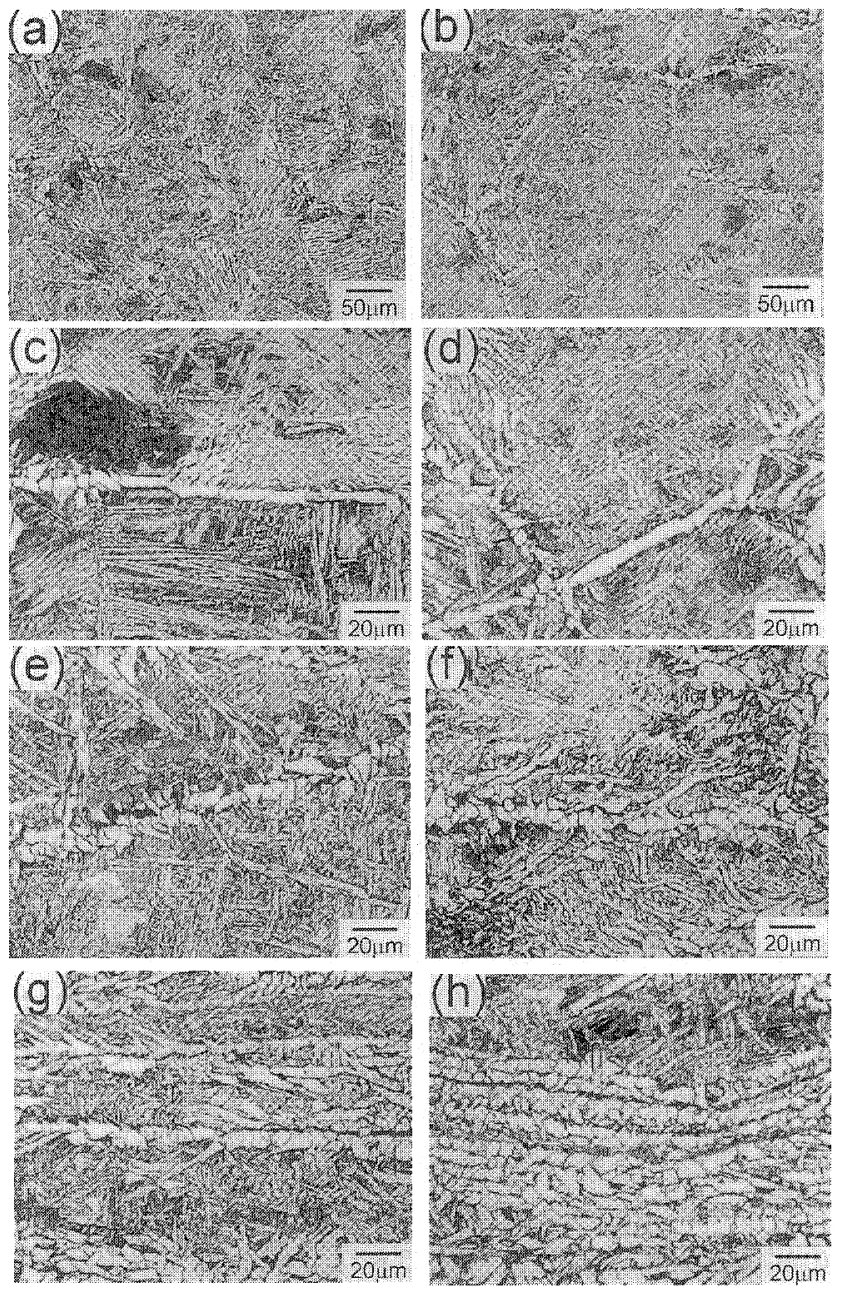

Fig. 2. Light micrographs of ferrite grains formed at austenite grain boundaries in the TD cross-section of the specimens which were compressed by 20,33 and $50 \%$ in reduction at $1023 \mathrm{~K}$ and then cooled at $10 \mathrm{~K} / \mathrm{s}$. Plastic strain was (a) 0 , (b) 0.05 , (c) 0.05 , (d) 0.2 , (e) 0.4 , (f) 0.78, (g) 0.95 and (h) 1.1 .

である。Fig. 3(a)から， $\alpha$ 粒の平均厚さ法塑性ひずみ $0.05-$ 1.0 の範囲では 6-7 $\mu \mathrm{m}$ とひずみによらず変化はなく，最小 值と最大值にも大きな変化はなかった。しかし，塑性ひず み1.1では $\alpha$ 粒の厚さは若干減少した。これは, Fig. 2(h)で 観察されたように， $\gamma$ 粒内からも等軸 $\alpha$ 粒が生成するよう になったことと関係があるのものと思われる。このように 塑性ひずみ 1.0 までの範囲では, 粒界 $\alpha$ 粒の形状は板状か ら等軸状に変化したが, 粒界に垂直な方向の $\alpha$ 粒の平均厚 さはほぼ一定である。

一方，Fig. 3(b)に示すように， $\alpha$ 粒の長さは，塑性ひず みが $0.05-0.3$ の場合, $30 \mu \mathrm{m}$ を越えるものも多く, 平均で も $10 \mu \mathrm{m}$ を越气る。このような粗大粒は塑性ひずみの増加 にしたがって減少し，塑性ひずみ 0.4 以上では長さ $30 \mu \mathrm{m}$ を越える粗大 $\alpha$ 粒は存在しない。一方，平均 $\alpha$ 粒長さに注 目すると，12 $\mu \mathrm{m}$ から塑性ひずみの増加とともに減少し，

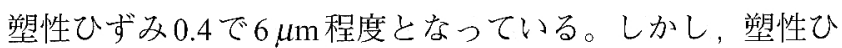
ずみ 0.5 以上では平均長さは变化せず一定となっている。 
(a)

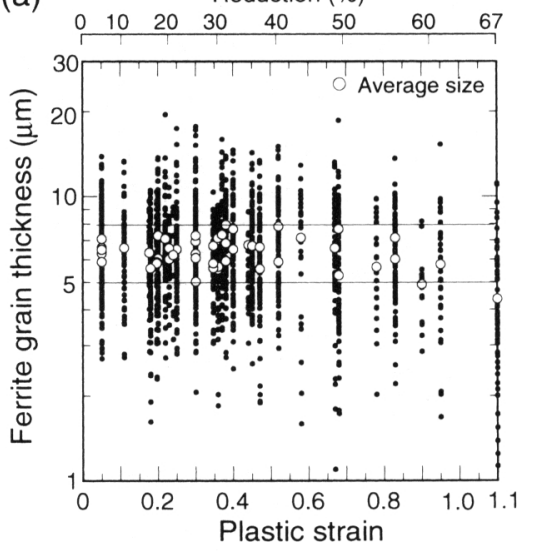

(b)

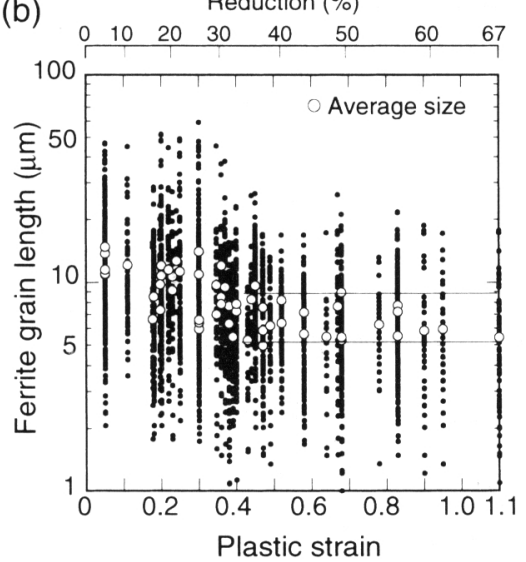

Fig. 3. Relationship between the plastic strain and (a) the thickness and (b) the length of ferrite grains formed at grain boundaries of austenite deformed at $1023 \mathrm{~K}$ and then cooled at $10 \mathrm{~K} / \mathrm{s}$. The thickness and length represent the grain size perpendicular and parallel to the austenite grain boundary, respectively. Solid circles and open circles represent the thickness or length of ferrite grains and their average, respectively.

このことは，本実験条件の場合，塑性ひずみ 0.4 (圧下率 $33 \%$ に相当）以上の大きな塑性変形を施しても粒界 $\alpha$ は微 細化されないことを示すものである。このように塑性ひず みの増加とともに粒界 $\alpha$ の大きさが飽和する現象は， Amano らが等温変態実験においてすでに報告しているの。 本研究の結果は, 連続冷却変態打よび等温変態に関わらず, 塑性ひずみが一定以上になると粒界 $\alpha$ の大さが飽和する ことを示している。しかし, Amanoらの報告では, 飽和

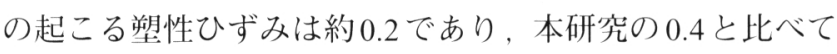
小さい。この飽和塑性ひずみの違いについては $4 \cdot 1$ 節で検 討する。

\section{$3 \cdot 2$ 粒界 $\boldsymbol{\alpha}$ 粒の結晶方位}

\section{$3 \cdot 2 \cdot 1$ 塑性ひずみ 0.05 の場合}

Fig. 4 は観察した旧 $\gamma$ 粒界が十分な平坦さを保っている 場合（塑性ひずみ 0.05）の旧 $\gamma$ 粒界近傍組織の SEM像の一 例である。ここでは7個の粒界 $\alpha$ 粒が観察される。ほとん どが板状であり，7個の $\alpha$ 粒の長さの平均值は $13 \mu \mathrm{m}$ であ る。ここで， $\alpha$ 粒3は母相B 側へ成長しており，他の6つ の $\alpha$ 粒は母相 $\mathrm{A}$ 側に成長している。粒界上析出物は粒界を

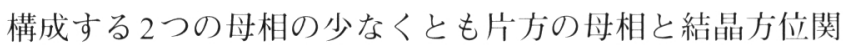
係存し, 結晶方位関係を持たない側の母相へ優先的に成 長すると報告されている ${ }^{13)}$ 。従って， $\alpha$ 粒 3 以外は母相 $\mathrm{B}$ と結晶方位関係をもって生成した可能性が高い。これら7 つの粒界 $\alpha$ 粒の方位解析結果孝, Fig. 5 の逆極点図上に示 す。図中の ND, RD, TD は Fig. 1に示す試料方位である。 $\alpha$ 粒(1，2，4，6，7)は只机ぞれ非常に近い結晶方位を持つこと がわかる。

Table 1に各 $\alpha$ 粒間の方位差角を示守。Table 1に扔いて， まず母相 A と結唱方位関係をもって生成したと考えられる $\alpha$ 粒 3 と他の $\alpha$ 粒の方位差角に注目する。 $\alpha$ 粒3 3 法， $\alpha$ 粒 $(1$, 2, 4, 6, 7)に対して 21.8-29.3， $\alpha$ 粒5に対しては37.1。の大き な方位差角を有している。次に，母相 B と結唱方位関係を

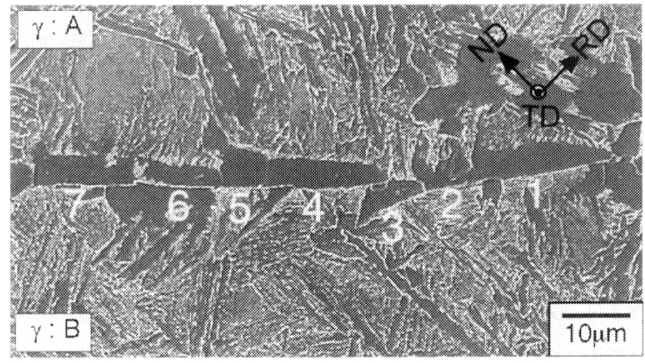

Fig. 4. SEM photograph of ferrite grains formed at an austenite grain boundary. The austenite was deformed by 0.05 in plastic strain at $1023 \mathrm{~K}$ and then cooled at $10 \mathrm{~K} / \mathrm{s}$.

もって生成したと考えられる6つの $\alpha$ 粒に打ける互いの方 位差角について見てみる。 $\alpha$ 粒 $(1,2,4,6,7)$ の互いの方位差 角は最大でも $4.9^{\circ}$ と小さく，同一バリアントの $\alpha$ と見なす ことができる。一方， $\alpha$ 粒 5 は他の5つの $\alpha$ 粒 $(1,2,4,6,7)$ と 8.8-11.30の方位差角を持っている。ところで, K-Sの関 係が満足される 24 通りのバリアント間に抢ける最小方位 差角は $10.5^{\circ}$ であり，最密面 $\{110\}_{\alpha}$ または最密方向 $\langle 111\rangle_{\alpha}$ を共有する 2 種類のバリアントが存在する ${ }^{14)}$ 。方位解析の 結果， $\alpha$ 粒 5 と他の $\alpha$ 粒 $(1,2,4,6,7)$ は最密面をほぼ共有す ることがわかった。すなわち， $\alpha$ 粒 5 と他の $\alpha$ 粒は, 晶癖 面在共有するわ忛であるが，Fig. 4からわかるように， $\alpha$ 粒 5 と他の $\alpha$ 粒 $(1,2,4,6,7)$ の $\alpha / \gamma$ 界面の向きはほぼ等しく 妥当である。

\section{$3 \cdot 2 \cdot 2$ 塑性ひずみ 0.78 の場合}

Fig. 6 は塑性ひずみ $0.78 の$ 場合の $\gamma$ 粒界近傍の SEM像の 1 例である。ここでは旧 $\gamma$ 粒界はND方向に垂直となって いる。网中には， $\alpha$ 粒の粒界をトレースした模式図を挿入 している。粒界 $\alpha$ 粒の多くは等軸状である。Fig. 6に示す 旧 $\gamma$ 粒界に沿った 1 から 27 番までの粒界 $\alpha$ 粒の方位を解析 した結果を，Fig. 7(a)の逆極点龱に示す。 $\alpha$ 粒の方位は 様々に分散しているが，ND方向では〈101〉, RD方向では 


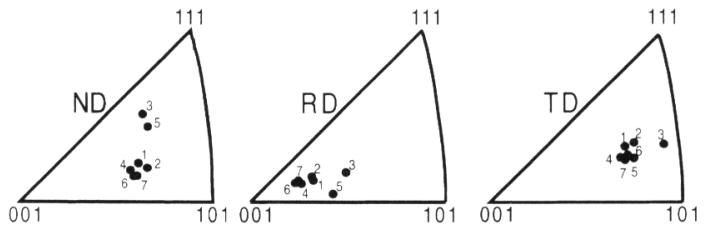

Fig. 5. Inverse pole figures of the crystallographic orientations of the ferrite grains formed at the austenite grain boundary shown in Fig. 4. The plastic strain was 0.05 .

Table 1. Misorientation angles $\left(^{\circ}\right)$ between the ferrite grains formed at an austenite grain boundary shown in Fig. 4. The plastic strain was 0.05 .

\begin{tabular}{|c|c|c|c|c|c|c|c|}
\hline No. & 1 & 2 & 3 & 4 & 5 & 6 & 7 \\
\hline 1 & & 2.3 & 29.3 & 3.2 & 8.8 & 4.2 & 3.5 \\
\hline 2 & & & 28.0 & 4.7 & 9.6 & 4.9 & 3.9 \\
\hline 3 & & & & 28.2 & 37.1 & 26.8 & 26.7 \\
\hline 4 & & & & & 10.3 & 1.7 & 2.0 \\
\hline 5 & & & & & & 11.3 & 11.1 \\
\hline 6 & & & & & & & \\
\hline 7 & & & & & & & \\
\hline
\end{tabular}

$\langle 111\rangle, \mathrm{TD}$ 方向については〈101〉に近い方位の $\alpha$ 粒は存在し ないことがわかる。特に強い方位の集積は認められないが， $\{113\}\langle 110\rangle$ 付近の方位の密度が若干高い。稲垣 ${ }^{7}$ ，柚鳥 $5^{8)}$ は，制御圧延鋼の $\alpha$ 組織の主要方位を $\{113\}\langle 110\rangle$, $\{332\}\langle 113\rangle$ と同定したが，本結果はこれと矛盾しない。

Fig. 7(b)の逆極点図は，粒界 $\alpha$ 粒の方位分散を示すもう 一つの例で，Fig. 6 と同様にND方向と垂直になった旧 $\gamma$ 粒 界に打いて観察解析したものである。Fig. 7(a)と(b)を比較 すると, ND执びTD方向に関し，〈101〉近傍の方位の $\alpha$ 粒はなく, RD方向については〈111〉近傍の方位の $\alpha$ 粒が存 在しないことが共通している。

Fig. 6に示した27個の $\alpha$ 粒間の方位差角を測定した結 果，すべての組合わせ 351 通りの平均方位差角は $33.9^{\circ}$ で あった。これら27個の $\alpha$ 粒のバリアントについて検討す る。Fig. 4 に示した塑性ひずみ 0.05 の場合, 同一バリアン 卜と判断した $\alpha$ 粒 $(1,2,4,6,7)$ の互いの方位差角は最大で も4.90であった。そこで方位差角 50 以内を同一バリアント と仮定すると，27個の $\alpha$ 粒のうち，粒 2-15 (4.2)のみで あった。この仮定にしたがうと，26個のバリアントが生 成していることになる。さらに，同一バリアントとして $8^{\circ}$ まで許しても，その組合わせは次の9つであり，組合わせ

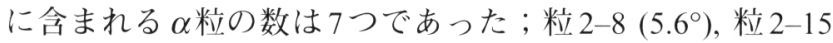
$\left(4.2^{\circ}\right)$, 粒 3-27 $\left(7.0^{\circ}\right)$, 粒 4-16 $\left(7.1^{\circ}\right)$, 粒 4-25 $\left(6.0^{\circ}\right)$, 粒 8-15 $\left(7.6^{\circ}\right)$, 粒 $11-17\left(7.7^{\circ}\right)$, 粒 20-22 $\left(7.7^{\circ}\right)$, 粒 $23-25\left(8.0^{\circ}\right)$ 。一 方，これらの組合わせに含まれない $\alpha$ 粒 20 個の互いの方 位差角はすべて $9.0^{\circ}$ 以上と大きく，それぞれバリアントが 異なると判断すべきである。したがって，27個の $\alpha$ 粒にお いて，少なくとも20個以上のバリアントが生成している と判断できる。すなわち, 塑性ひずみ 0.780 場合, 生成す る粒界 $\alpha$ 粒のバリアントに優先性はなく，これはFig. 7の

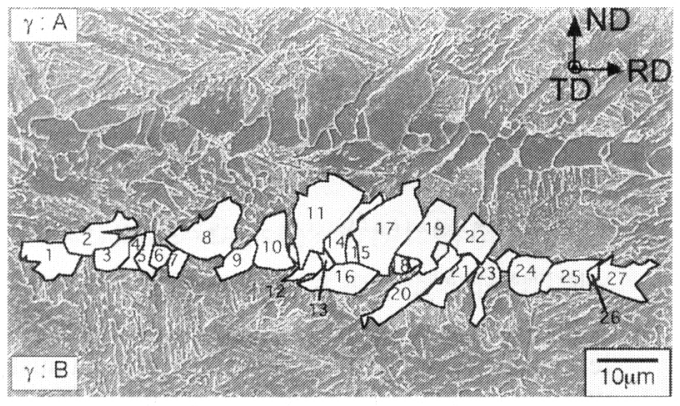

Fig. 6. SEM photograph of ferrite grains formed at an austenite grain boundary. The austenite was deformed by 0.78 in plastic strain at $1023 \mathrm{~K}$ and then cooled at $10 \mathrm{~K} / \mathrm{s}$.
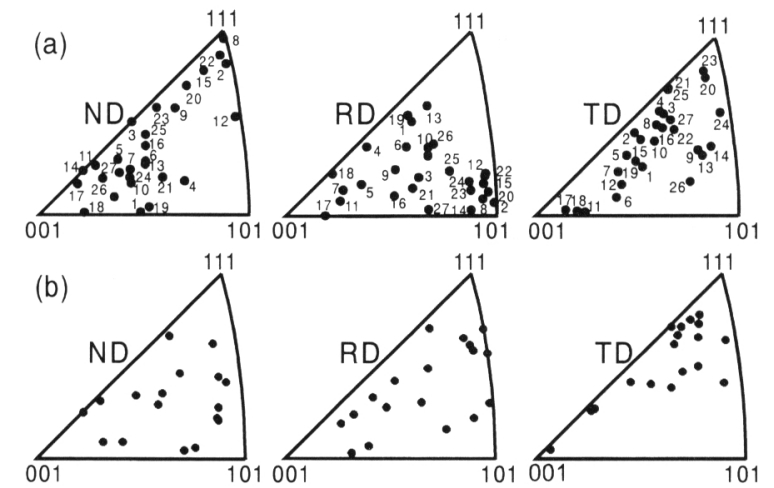

Fig. 7. Inverse pole figures of the crystallographic orientations of the ferrite grains formed at the austenite grain boundary. The plastic strain was 0.78 . (a) The orientations of the ferrite grains shown in Fig. 6 and (b) the orientations of the ferrite grains formed at another grain boundary.

逆極点罒にも示したとおりである。また，27個の $\alpha$ 粒間に は320粒界が存在するが，そのうち隣接 $\alpha$ 粒の方位差角 $15^{\circ}$ 末満の小角粒界は， $\alpha$ 粒界3-4 (13.7 ), $\alpha$ 粒界 17-18 (11.1 ${ }^{\circ}$ およよ゙ $\alpha$ 粒界20-22 (7.7)の3つのみであり，す心゙て の粒界の平均方位差角は $35.9^{\circ}$ であった。

\section{4. 考察}

\section{$4 \cdot 1$ 粒界 $\alpha$ 粒の等軸・微細化}

Fig. 3(a)に示したように，塑性ひずみが1までの範囲で は, 塑性ひずみが増加しても粒界 $\alpha$ 粒の厚さは変化しな かった。この結果は, 粒界 $\alpha$ 粒の成長速度に及ぼす $\gamma$ 塑 性変形の影響が非常に小さいことを示して抢り，すでに Umemoto ${ }^{15)}$ によって指摘されている。 $\alpha$ 粒の成長速度式 における parabolic rate constant $A$ は式( 1 )で表される。

$$
A=\sqrt{\frac{D\left(C_{\gamma}-C_{0}\right)^{2}}{\left(C_{0}-C_{\alpha}\right)\left(C_{\gamma}-C_{\alpha}\right)}}
$$

ここで，Dは $\gamma$ 中の炭素の拡散係数， $C_{\gamma}, C_{\alpha}$ は，それぞれ， $\gamma / \alpha$ 界面の $\gamma$ 側扰よび $\alpha$ 側の平衡炭素濃度, $C_{0}$ は変態前の $\gamma$ 中の平均炭素濃度である。式(1)から， $\gamma$ の塑性変形に 


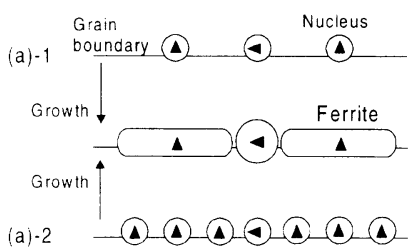

(a) Plastic strain $=0.05$

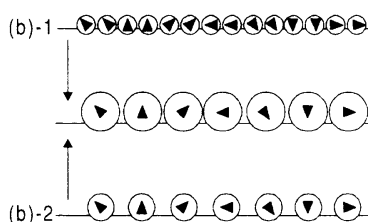

(b) Plastic strain $=0.78$
Fig. 8. Schematic drawing of nucleation, growth and coalescence of the ferrite grains formed at an austenite grain boundary. The triangle in the circle represents the crystallographic orientation of the ferrite grains.

よって $D, C_{\gamma}, C_{\alpha}$ が変化すれば， $\alpha$ 粒の成長速度が影響を受 けることがわかる。Umemotoらは15)，塑性変形を受けた $\gamma$ はひずみエネルギーの増加によって $C_{\gamma}$ が大きくなる可能 性を述べているが, 冷間強加工で得られるような転位密度 $2.5 \times 10^{11} / \mathrm{cm}^{2}$ に相当する $50 \mathrm{~J} / \mathrm{mol}$ という大きなひずみエネ ルギーを与えても $\alpha$ の成長速度の増加はせいぜい $10 \%$ 以下 と見積もっている。彼らの検討結果に従えば, 本実験で用 いた加工温度 $1023 \mathrm{~K} て ゙ は$ 泠間加工と比べて $\gamma$ 中に導入され る転位密度は低く、ひずみエネルギーによる成長速度の增 加は無視できることになり，Fig. 3(a)の結果は妥当と考え る。

$\alpha$ 粒の長さについては, Fig. 3(b)に示したように, 塑性 ひずみ 0.4 まではひずみの増加とともに平均長さが減少し， 塑性ひずみ 0.4 以上では平均長さはほぼ一定となった。 Fig. 4に示した塑性ひずみ 0.05 の場合，アスペクト比が 2 以上の板状の $\alpha$ 粒が主であったが，その生成の推定図を Fig. 8(a)に示す。飴山らは ${ }^{4)}, \gamma$ 化温度を高温として十分粒 成長させた場合の直線的 $\gamma$ 粒界に生成する板状の $\alpha$ 粒内部 には亜粒界が存在することを明らかにし，同一バリアント の $\alpha$ 粒が合体した結果であると報告している。したがって， Fig. 4 の板状 $\alpha$ 粒 $(1,2,4,6,7)$ も 単独の粒がそれぞれ成長 した(Fig. 8(a)-1)というよりも，Fig. 8(a)-2に示すようにそ れぞれ複数の同一バリアントの $\alpha$ 粒が成長して合体したと 考える方が妥当であろう。Fig. 4 の $\alpha$ 粒 5 は等軸粒である が, Table 1で述べたように他の $\alpha$ 粒と異なるバリアントで あった。このため隣接 $\alpha$ 粒との合体が抢こらず等軸微細に 保持されたと考えることができる。

塑性ひずみ 0.4 までは，ひずみの増加とともに粗大な板 状 $\alpha$ の生成が抑制され，粒界 $\alpha$ の平均長さが減少した(Fig.

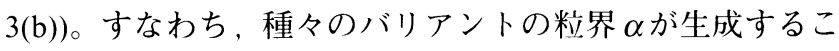
とによって隣接 $\alpha$ 粒の合体が抑制され，平均 $\alpha$ 粒長さが減 少したわけである。この場合，Fig. 8(b)-2に示すように， 単位粒界面積あたりの核生成頻度が塑性ひずみ $0.05 の$ 場合 (Fig. 8(a)-2)と同程度であったとしても， $\alpha$ 粒の結晶方位が 様々に分散することによって $\alpha$ 粒の合体が抑制され，結果 として微細な $\alpha$ 粒組織が形成されるという機構を考えるこ とができる。もちろん，Fig. 8(b)-1に示すように，核生成
頻度の増加と結晶方位の分散が同時に生じたことも考えら れる。しかし，隣接 $\alpha$ 粒のバリアントが同じであれば合体 が生じ，核生成頻度の増加が微細化に有効に作用しないこ ともありえる。本研究の結果は, 粒界 $\alpha$ 粒の微細化のため には，単なる核生成頻度の増加は意味が無く，異なるバリ アントの $\alpha$ 粒を数多く生成させることが重要であることを 再認識させるものである。

本研究における重要な知見として，Fig. 3(b)に示したよ うに塑性ひずみ 0.4 以上では $\alpha$ 粒の長さが変化しないこと があげられる。近年, 強加工を利用した $\alpha$ 粒の微細化が検 討されているが, 本研究の結果は, 単なる強加工の付与で は粒界 $\alpha$ 粒を微細化できないことを示すもので重要であ る。 $\gamma$ 粒界からの $\alpha$ 粒の生成は, $\gamma$ 粒拉よび近傍の変形組 織と密接に関係するはずである。したがって，塑性ひずみ 0.4 以上において変形組織が一定であれば，粒界 $\alpha$ の生成 にも変化がないことになる。高温変形においては最初ひず みとともに変形応力が增加した後に変形応力が一定とな る、いわゆる動的回復型の応力ーひずみ曲線を描くことが 良く知られている。さらに, 定常応力状態ではセルサイズ などの変形微視組織も変化しないことが知られている。そ こで, 本研究で用いた試料の高温での応力ーひずみ曲線を 検討するために, 直径 $8 \mathrm{~mm}$ 高さ $12 \mathrm{~mm}$ の円柱試験片を用 いて圧縮試験機による実験を行った。結果をFig.9に示す。 ひずみ速度 $10 / \mathrm{s}$ の場合, 定常応力状態となるひずみは変形 温度の低下とともに若干增加しているが，いずれの場合も 圧下率 30\%（ひずみ 0.36）以上でほぼ定常応力状態となっ ていることがわかる。この結果は，動的回復のために $\gamma$ の 変形微視組織が高ひずみでは変化しないことを示すもの で、このために粒界 $\alpha$ 粒の大きさが高ひずみ域では一定で あったことが示唆される。

緒言および $3 \cdot 1 \cdot 2$ 節でも述べたように, 塑性ひずみが 一定量以上になると粒界 $\alpha$ の大さが飽和する現象はすで にAmanoらが等温変態実験において報告しているが，飽

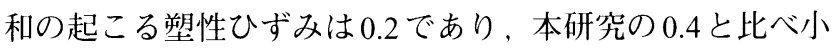
さい。Amanoらは, 本研究とほぼ同じ組成の $0.15 \mathrm{C}-0.3 \mathrm{Si}-$ 1.3Mn鋼を試料として用いている。また，973-893K と等 温変態温度を変化させても飽和ひずみは約 0.2 と变わらな いと報告している。したがって, 飽和ひずみの違いの原因 を試料化学組成のわずかな差や変態温度域の違いに求める ことは難しい。前述の考え方にしたがうならば，両研究に おいて加工条件が違い, 定常応力状態となるひずみが異 なったと考えるべきである。加工温度は本研究では $1023 \mathrm{~K}$ であり, Amanoらは1073Kである。ひずみ速度は本研究で は10/sであり，Amanoらの報告では記述されていない。

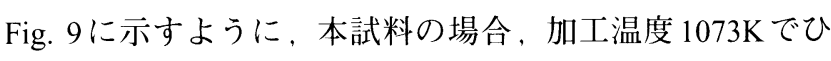
ずみ速度を低下させると定常応力状態となるひずみが減少 する傾向にある。したがって，Amanoらの用いたひずみ 速度が本研究と比べて小さければ, 応力一ひずみ曲線の形 


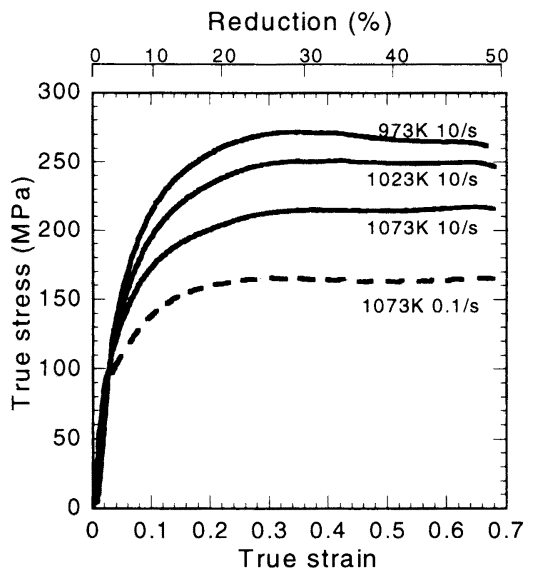

Fig. 9. Stress-strain curves of the steel used. Cylindrical specimens were compressed at 973, 1023 and $1073 \mathrm{~K}$ at a strain rate of $10 / \mathrm{s}$ for solid curves and at $1073 \mathrm{~K}$ at a strain rate of $0.1 / \mathrm{s}$ for a broken curve.

から，粒界 $\alpha$ の微細化が飽和する塑性ひずみの違いを説明 することが可能である。しかし，詳細は今後の実験が必要 である。

\section{$4 \cdot 2$ 粒界 $\alpha$ 粒の結晶方位の分散化}

$\gamma$ 粒界からの $\alpha$ 変態では, $\gamma$ 粒界を構成する $2 つ の ~ \gamma$ 粒の いずれかと K-S関係を満足する合計 48 通りのバリアント が選択可能である。48通りのバリアントの存在にもかか わらず特定のバリアントの粒界 $\alpha$ が優先的に選択される原

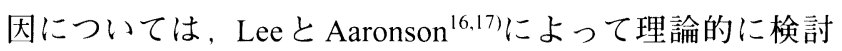

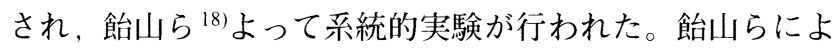
れば，粒界 $\alpha$ は $\gamma$ 粒界を構成する $2 つ の ~ \gamma$ 粒のいずれか一 方と K-Sの関係を満たして生成する。このとき，まず，そ の $\gamma$ 母相の 4 つの最密面 $\{111\}$ のうち $\gamma$ 粒界面に対して, な す角の最も小さな面を $\mathrm{K}-\mathrm{S} の$ 面平行関係にもつバリアント が選択される。これは $\alpha$ の晶癖面が $\{111\}_{\gamma}$ で, 晶癖面と粒 界面のなす角が小さい方が $\alpha$ 核生成による $\gamma$ 粒界の消滅面 積が大きく，核生成の活性化エネルギーが減少するためで ある。このような晶癖面 $\{111\}_{\gamma}$ と粒界面の関係からバリア ントは6通りに制限される。この中から，K-S関係を有さ ない側の $\gamma$ に対して最も整合性がよいバリアントが存在す るときに，単一のバリアントが選択されることになる。

本研究では, 塑性ひずみ 0.05 の場合(Fig. 4, 5)， $\alpha$ 粒は板 状が支配的で優先的なバリアントが観察された。また， Fig. 2(d)に示したように塑性ひずみ 0.2 までは, 板状の $\alpha$ 粒 が生成する $\gamma$ 粒界が認められた。この結果は, 飴山らの指 摘にしたがえば，塑性ひずみ 0.2 までは，平坦な $\gamma$ 粒界が 存在することを意味する。そして，隣接 $\alpha$ 粒の合体による 粗大板状 $\alpha$ 粒の形成を抑制するためには，本実験条件では 塑性ひずみ 0.4 （压下率 $33 \%$ に相当）以上の塑性変形を与 える必要があることがわかった(Fig. 2, 3)。

塑性ひずみ 0.78 の場合, Fig. 6と Fig. 7に示したように, 粒界 $\alpha$ 粒のバリアントの選択に優先性は認められず種々の
バリアントが生成していた。このようなバリアントの分散 化の要因として次の3つをあげることができる。第 1 は, 塑性変形によって局所的な結晶方位回転が起こり粒界近傍 の $\gamma$ の結晶方位が変化することである。第2に，Furuhara ら ${ }^{19)}$ が指摘したように, 粒界近傍に蓄積した転位の応力場 の影響が考えられる。転位蓄積による応力状態が一つの粒 界の場所場所で異なれば，生成する $\alpha$ 粒のバリアントが変 化する可能性がある。第3に, 塑性変形によって $\gamma$ 粒界面 が局所的に変化することがあげられる。粒界面方位が変化 すれば粒界 $\alpha$ 粒のバリアントが変化することは飴山ら ${ }^{18)}$ 指摘したとおりである。

第1の要因である塑性変形による粒界近傍の局所的な結 晶回転については, 最近著者らの一部が, 室温でも fcc 相 が安定な $\mathrm{Fe}-36 \mathrm{Ni}$ インバー合金を用いて検討を行ってい る ${ }^{20)}$ 。本研究と同じ加工温度 $1023 \mathrm{~K}$ とひずみ速度 10/sで, 本研究よりも大きな圧下率 $75 \%$ を与え, 変形後に水冷し て粒界近傍の組織をTEM観察した。その結果, 粒界近傍 の結晶方位変化は数度以下と小さいことを明らかにした。 したがって、粒界 $\alpha$ のバリアントの分散化は, 粒界近傍の 母相 $\gamma$ の結晶方位変化では説明できないと考える。

第2の要因である転位蓄積による応力状態については明 確なことはいえないが，上述したインバー合金を用いた TEM 観察によると粒界近傍の変形組織はセル組織で，粒 界に沿ってセル組織や結晶方位に大きな変化が認められな かったことから，その影響は小さいと考える。

第3の要因である粒界面の局所的な変化を検討するため に，高温変形したインバー合金の粒界組織を観察した。一 例を Fig.10に示す。加工温度 1023K，ひずみ速度 10/s, 圧下 率 $75 \%$ で圧縮した試料の塑性ひずみ 0.8 の領域の光学顕微 鏡組織である。粒界は $4 \mu \mathrm{m}$ 程度の周期で凸凹している。 このような高温変形による粒界の凸凹化は，1023Kで変形 して焼入れた $\mathrm{Fe}-2 \mathrm{Mn}-0.36 \mathrm{C}$ 合金マルテンサイト組織の旧 $\gamma$ 粒界でも観察されている21.22)。したがって, 本研究の試 料の場合, 変形後に水焼入れを行っても $\gamma$ 粒界からの $\alpha$ 粒 の生成を抑制することができず $\gamma$ 粒界の形状を観察するこ とはできなかったが， $\gamma$ 粒界にはFig.10に示したような凸 凹が導入されていたと推察できる。このように粒界面が局 所的に様々に変化するために, 粒界 $\alpha$ 粒の優先生成バリア ントが局所的に変化して, 結果的に様々なバリアントの $\alpha$ 粒がひとつの $\gamma$ 粒界から生成したと考える。つまり，粒界 $\alpha$ 粒の微細化のためには, 単なる核生成頻度の増加は意味 が無く，異なるバリアントの $\alpha$ 粒を数多く生成させること が必要であるが, バリアントの分散化のためには $\gamma$ 粒界面 の凸凹化すなわち粒界面方位の局所的な変化が重要である と考える。

ところで，柚鳥ら ${ }^{8}$ は制御圧延鋼の变態集合組織に関し て, 集合組織の集積度が圧延後（50 $80 \%$ 圧延）の冷却速 度によって変化することを報告している。すなわち， $\alpha+$ 


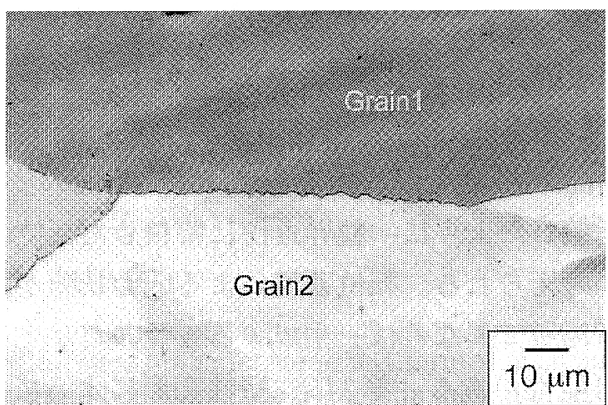

Fig. 10. Light micrograph of a serrated austenite grain boundary of $\mathrm{Fe}-36 \mathrm{Ni}$. The austenite was deformed by 0.8 in plastic strain at $1023 \mathrm{~K}$ and then water-quenched.

パーライト $(\mathrm{P})$, アシキュラー $\alpha$, マルテンサイトのけずれ においても変態集合組織の主方位は $\{113\}\langle 110\rangle,\{332\}\langle 113\rangle$ であるが， $\alpha+\mathrm{P} に$ に方主方位の集積度はアシキュラー $\alpha$ とマルテンサイトに比べ弱いと報告している。このことは， 加工硬化 $\gamma$ からの相変態の場合, 粒界上変態生成物は本研 究で明らかになったように特定バリアントの優先性がない のに対して，必ずしも $\gamma$ 粒界上から生成しないマルテンサ イトやアシキュラー $\alpha$ では，バリアントの優先性が強いと すれば，うまく説明ができる。実際に，古原らは $\beta$ 型子タ ン合金の加工された母相 $\beta$ 粒内から $\alpha$ 粒が生成する場合， $\alpha$ 粒のバリアントは著しく制限されることを示してい る ${ }^{23)}$ 。柚鳥らが用いた試料の $\gamma$ 粒径は $30 \mu \mathrm{m}$ と小さく, $\alpha+\mathrm{P}$ 組織を形成する $\alpha$ 粒の大半は $\gamma$ 粒界から生成したと考 えてよく，粒界 $\alpha$ 粒には特定バリアントの優先性がないた めに主方位の集積度が弱くなったと解釈できる。すなわち， 変形 $\gamma$ 粒界を主たる $\alpha$ 生成サイトとすれば, 弱い変態集合 組織の鋼が得られ， $\gamma$ 粒内を主たる $\alpha$ 生成サイトとすれば 強い変態集合組織の鋼が得られることになり，今後の材料 設計の一つの指針としたい。

\section{5. 結言}

SM490相当の低合金鋼 $(0.17 \mathrm{C}-0.3 \mathrm{Si}-1.5 \mathrm{Mn}, \gamma$ 粒径 $300 \mu \mathrm{m}) に$ 抢いて，塑性変形を受けた $\gamma$ 粒界から生成す る $\alpha$ 粒の形, 大きさ, 結晶方位に及ぼす塑性ひずみの影響 について検討を行い，以下の結論を得た。

（1）塑性変形を受けた $\gamma$ 粒界に生成する $\alpha$ 粒の形は, 塑性ひずみ 0.2 以下ではアスペクト比 2 以上の板状である が，塑性ひずみ 0.4 以上では等軸状となる。

(2) 塑性変形を受けた $\gamma$ 粒界に生成する $\alpha$ 粒において， $\gamma$ 粒界に垂直方向の粒切片（厚さ）泣塑性ひずみ $0.05-1.0$ の範囲で变化せず 6-7 $\mu \mathrm{m}$ 程度である。一方, 粒界に平行 な方向の $\alpha$ 粒切片（長さ）は， $12 \mu \mathrm{m}$ から塑性ひずみの増

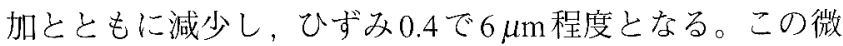
細化は, 板状 $\alpha$ の生成頻度の低下に起因する。しかし, 生 成する $\alpha$ 粒が等軸状となる塑性ひずみが 0.4 から 1.0 の範囲
では $\alpha$ 粒長さは変化しない。

(3) 塑性ひずみ $0.05 の$ 領域の $\gamma$ 粒界から生成する $\alpha$ 粒 のバリアントには優先性があり，互いに近い結晶方位の $\alpha$ 粒が多く生成する。このため， $\alpha$ 粒界の大半は小角粒界と なる。一方，塑性ひずみ 0.780 領域の $\gamma$ 粒界から生成した $\alpha$ 粒のバリアントには優先性がなく，さまざまな結晶方位 の $\alpha$ 粒が生成する。このため $\alpha$ 粒界の大半は方位差角 $15^{\circ}$ 以上の大角粒界となる。

（4） $\alpha$ 粒の等軸化および微細化には，塑性ひずみによ る単位粒界面積あたりの核生成頻度の増加以前に, $\gamma$ 粒界 から変態生成する $\alpha$ 粒の結晶方位が様々に分散することが 重要である。この結晶方位の分散化は，塑性変形によって $\gamma$ 粒界に凸凹が生じ粒界面方位が局所的に変化することに 起因守る。

本研究の遂行にあたり，ひずみ分布解析に関して金属材 料技術研究所井上忠信工学博士に多大なご協力をいただい た。

\section{文献}

1）小指軍夫著：制御压延 - 制御冷却、日本鉄鋼協会監修，地人 書館, 東京, (1997), 35 .

2 ) M.Umemoto, H.Otsuka and I.Tamura: Tetsu-to-Hagané, 70 (1984), 557.

3 ) K.Tsuzaki: J. Jpn. Soc. Heat Treat., 38 (1998), 146.

4 ) K.Ameyama, M.Minagawa, T.Maki and I.Tamura: Tetsu-to-Hagané, 74 (1988), 1839

5 ) M.Umemoto, H.Ohtsuka, H.Kato and I.Tamura: Proc. Int. Conf. on High Strength Low Alloy Steels, ed. by D.P.Dunne et al., South Coast Printers, Port Kembla, (1984), 107.

6 ) K.Amano, T.Hatomura, M.Koda, C.Shiga and T.Tanaka: Proc. Int Symp. on Accelarated Cooling of Steels, ed. by P.D.Southwick, AIME, Pittsburgh, (1986), 349

7 ) H.Inagaki: Trans. Iron Steel Inst. Jpn., 17 (1977), 166

8 ) T.Yutori and R.Ogawa: Tetsu-to-Hagané, 65 (1979), 1747.

9) T.Ohashi, S.Torizuka, T.Inoue, K.Tsuzaki and K.Nagai: CAMP-ISIJ, 11 (1998), 1190

10) 国尾 武著：固体力学の基碟，培風館，東京，(1977), 219 .

11) V.Randale: Microtexture Determination and its Application, The Institute of Materials, London, (1992), 82.

12）飴|山 恵：立命館大学工学研究所紀要, 51 (1992), 1.

13) M.Hillert: The Decomposition of Austenite by Diffusional Processes, ed. by V.F.Zakay et al., Interscience, New York, (1962), 197.

14) S.Morito, H.Tanaka, T.Furuhara and T.Maki: Proc. 4th Int. Conf. on Recrystallization and Related Phenomena, ed. by T.Sakai et al., JIM, Sendai, (1999), 300 .

15) M.Umemoto, H.Ohtsuka and I.Tamura: Proc. Int. Conf. on Physical Metallurgy of Thermomechanical Processing of Steels and Other Metals (THERMEC-88), Vol. 2, ISIJ, Tokyo, (1988), 769.

16) J.K.Lee and H.I.Aaronson: Acta. Metall., 23 (1975), 799.

17) J.K.Lee and H.I.Aaronson: Acta. Metall., 23 (1975), 809.

18) K.Ameyama, T.Maki and I.Tamura: J. Jpn. Inst. Met., 50 (1986), 602.

19) T.Furuhara, S. Takagi, H.Watanabe and T.Maki: Metall. Mater. Trans. A, 27A (1996), 1635

20) O.Umezawa, S.Torizuka and K.Nagai: CAMP-ISIJ, 13 (2000), 489

21) S.Yusa, T.Hara, K.Tsuzaki and T.Takahashi: Mater. Sci. Eng., A273275 (1999), 462.

22) T.Hara, S.Yusa and K.Tsuzaki: Proc. Int. Conf. on Solid-Solid Phase Transformation'99(JIMIC-3), ed. by M.Koiwa et al., JIM, Sendai, (1999), 1549.

23) T.Furuhara, H.Nakamori and T.Maki: J. Jpn. Inst. Met., 56 (1992), 1020 . 